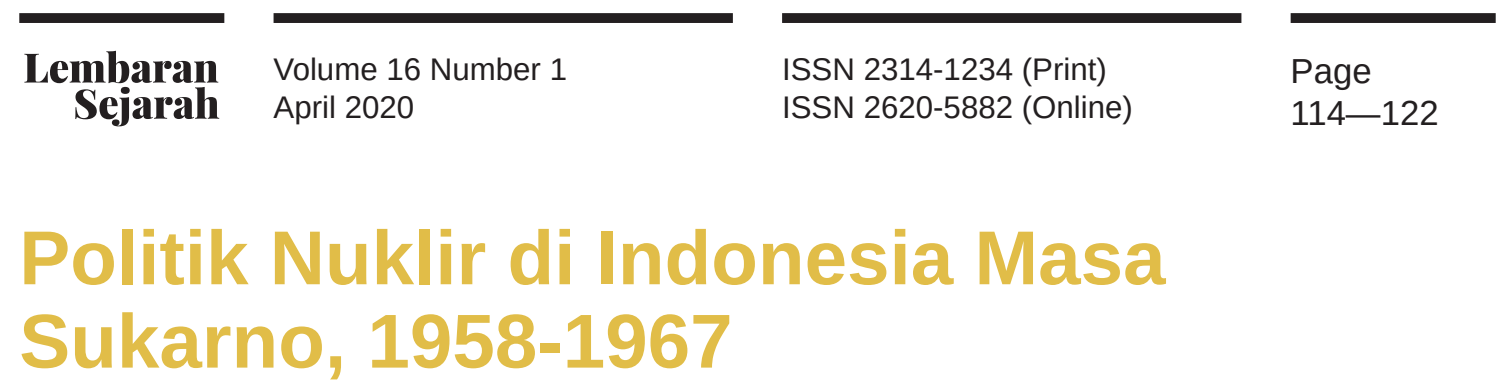

\title{
DARA SYLVIA
}

Mahasiswa Magister Sejarah UGM

Email: darasylvia@mail.ugm.ac.id

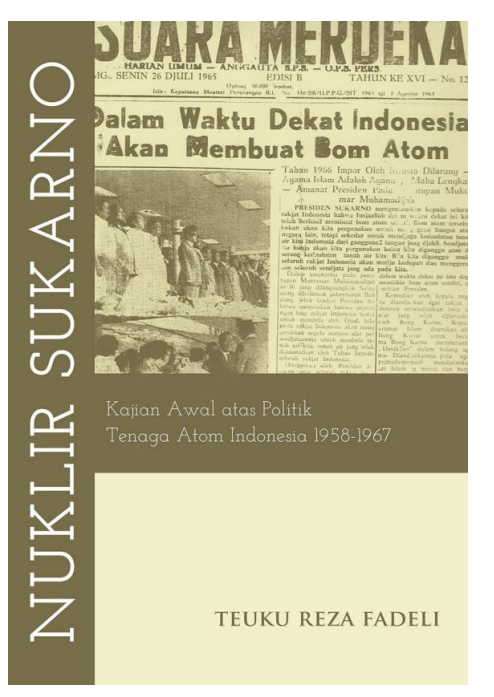

\section{Title:}

Nuklir Sukarno: Kajian Awal atas Politik Tenaga Atom Indonesia 1958-1967

\section{Author:}

Teuku Reza Fadeli

\section{Publisher:}

Marjin Kiri, Tangerang (2021)

Pages:

ix +104

ISBN:

978-602-078-813-5

Penulisan sejarah sains dan teknologi dalam historiogradi Indonesia, khususnya, dapat dikatakan masih sangat minim. Historiografi Indonesia hingga dewasa ini belum banyak mengeksplorasi sains dan teknologi sebagai objek material. Kranzberg (1962) menyatakan bahwa sejarah sains dan teknologi sama halnya seperti sejarah para raja dan jenderal, pemberontakan dan pergolakan ideologi, dan lain sebagainya yang merupakan bagian dari elemen-elemen pembentuk masa lalu. Dengan demikian, kedua ihwal tersebut, pada dasarnya, tidak bisa diabaikan dalam penulisan sejarah kita.

Buku berjudul Nuklir Sukarno: Kajian Awal atas Politik Tenaga Atom Indonesia 19581967 yang disusun oleh Teuku Reza Fadeli memberikan kontribusi yang luar biasa dalam menghadirkan kebaruan dalam pengembangan wacana historiografi Indonesia. Historiografi Indonesia, khususnya pada periode pasca kemerdekaan, dipenuhi oleh wacana politik, ekonomi, sosial, dan budaya, yang mana mengesampingkan wacana tentang teknologi. Padahal, pada tahun 1960an, terjadi persinggungan antara negara dan teknologi yang kental terasa, ketika kebijakan terkait teknologi nuklir menentukan nasib Indonesia dalam lintasan sejarah. Buku yang berasal dari tugas akhir skripsi ini, melihat bagaimana sains dan teknologi - dalam hal ini teknologi nuklir - turut mewarnai konstelasi politik Indonesia pada masa Sukarno. 
Buku ini mengulas bagaimana pemanfaatan teknologi nuklir membawa konsekuensi besar terhadap perubahan sosial dan politik di Indonesia pada tahun 1960an, dilihat dari faktor eksternal maupun internal. Sikap Sukarno yang paradoks terkait kepemilikan dan kegunaan nuklir dijelaskan sangat rinci dalam buku ini. Atas sikap Sukarno tersebut, negara-negara blok Barat di kemudian hari menunjukkan sikap waspada terhadap ambisi nuklir Sukarno yang mendapat sokongan kuat oleh Republik Rakyat Cina (RRC).

Pada bagian pendahuluan, penulis mencoba mengantarkan para pembaca untuk memiliki keinsayafan terkait penulisan sejarah sains dan teknologi; tentang bagaimana teknologi nuklir mulai dikembangkan pada abad 20 dan terjadinya perlombaan pengembangan senjata nuklir antara negara-negara adikuasa; serta dalam sub bab khusus, penulis mencoba meguraikan secara singkat tentang dinamika kebijakan Sukarno terkiat nuklir yang paradoksikal.

Bagian pertama buku ini menguraikan konstelasi perlombaan nuklir di dunia dan tendensi Indonesia semasa terjadinya Perang Dingin, pun bagaimana pandangan dan pemikiran Sukarno mengenai teknologi nuklir. Pada bagian kedua, buku ini menjelaskan tentang terbentuknya LTA yang kemudian berubah menjadi BATAN bersamaan dengan perubahan orientasi Sukarno yang dipengaruhi kondisi politik global dan imperliasme Barat yang terus menggeliat. Bagian terakhir buku ini, melihat ambisi Sukarno terhadap kepemilikan senjata nuklir Indonesia, tanggapan dunia internasional terkait hal itu, dan berakhirnya politik nuklir Sukarno bersama dengan berakhirnya kekuasannya.

\section{Pengembangan Teknologi Nuklir dan Orientasi Awal Sukarno}

Pasca peristiwa pengeboman Hiroshima dan Nagasaki pada tahun 1945, teknologi nuklir menjadi senter pembicaraan sehari-hari masyarakat dunia. Dengan terjadinya peristiwa tragis itu, anggapan orang-orang terkait nuklir selalu berkaitan dengan hal-hal yang sifatnya destruktif. Nuklir pada dasarnya bukan merupakan suatu hal yang baru bagi peradaban manusia - sinar matahari yang dirasakan oleh manusia juga merupakan reaksi fusi nuklir di matahari. Dengan demikian, nuklir memiliki manfaat, terlebih jika dikembangkan dengan baik dan benar, khususnya di bidang listrik, pertanian, industri, kesehatan dan hal yang berguna untuk pembangunan peradaban.

Teknologi nuklir pada dasarnya terkait dengan reaksi dari inti atom. Dalam awal abad ke-20, reaksi pembelahan inti atom mulai diteliti, dan hasilnya adalah yang dikenal sebagai reaksi nuklir. Dari daya teknologi nuklir yang besar tersebut, manusia pada waktu itu telah mencapai kemajuan dalam berbagai bidang, seperti yang telah disebutkan sebelumnya. Walakin, pemanfaatan teknologi nuklir sebagai senjata perang telah disadari sejak awal - yang kemudian mempercepat riset nuklir pada masa itu. 
Pasca Perang Dunia II, dunia memasuki sebuah periode baru, yaitu atomic age. Periode ini ditandai dengan saling berlombanya negara-negara dunia dalam mengembangkan teknologi nuklir, baik untuk keperluan damai maupun militer. Pada periode ini pula, muncul dua negara adidaya, sebagai pemenang perang dan pemimpin blok politik-ideologis yang saling bertentangan, yakni Amerika Serikat dan Uni Soviet. Keduanya melancarkan perang yang tak kasat mata, namun juga tidak tertutup sama sekali keahadirannya, yang dikenal sebagai Perang Dingin. Perang yang tak kasat mata ini sejatinya merupakan unjug kebolehan ideologi, ekonomi, dan politik antara kapitalisme yang diwakili oleh Amerika Serikat dan komunisme yang diwakili oleh Uni Soviet. Di gelanggang, terjadi perlombaan pengembangan senjata, sebagai upaya perimbangan kekuatan sekaligus peguatan instrumen pertahanan dan keamanan masing-masing negara.

Adanya syak wasangka Amerika Serikat terhadap Uni Soviet dalam berbagai hal, membuat Amerika Serikat (AS) menghambat laju komunisme di dunia, dibantu oleh para sekutunya. Terkait nuklir, kecurigaan tersebut telah membuat AS mengampanyekan program atoms of peace, agar riset nuklir digunakan untuk maksud dan tujuan damai, untuk pengembangan teknologi, bukan senjata. Tentu, kampanye AS ini mengandung tujuan pragmatis agar Uni Soviet tidak bisa menyamai kedudukan AS sebagai penguasa persenjataan nuklir.

Pada 29 Juli 1957, lahir International Atomic Energy Agency (IAEA) melalui berbagai ratifikasi di Washington - setelah melalui proses yang cukup panjang sejak tahun 1953. Dalam pendirian kelembagaan tersebut, Indonesia turut berkontribusi sebagai salah satu panitia. Pada konferensi pertama IAEA 1-23 Oktober 1957 di Wina, Indonesia mengirimkan beberapa delegasi. Perlu diketahui bahwa badan ini berusaha untuk mempercepat dan memperbesar sumbangan teknologi nuklir dalam bidang perdamaian, kesehatan, dan kemakmuran seluruh negara dunia; serta menjamin agar segala bantuan yang diberikan tidak disalahgunakan untuk kepentingan militer.

Indonesia selaku anggota IAEA wajib urun dana sebesar AS\$29.836,10. Tak hanya itu, Indonesia harus melakukan beberapa kegiatan seperti mendirikan lembaga nasional yang bergerak di bidang nuklir, sebagai persiapan dalam menghadapi atomic age. Hal ini sejalan dengan ambisi Sukarno agar Indonesia tak tertinggal di bidang teknologi modern. Dalam situasi Perang Dingin, pada dasarnya Sukarno menentang adanya perlombaan sejanta, baik senjata konvensional maupun senjata nuklir yang akan menyebabkan perang dan malapetaka di seluruh dunia. Ia menyatakan dengan tegas menyatakan bahwa Indonesia tidak memiliki keterkaitan mengembangkan persenjataan nuklir karena bertentangan dengan prinsip Indonesia terkait perdamaian dunia. Tetapi, ini bukan berarti Sukarno menentang politik tenaga nuklir, justru ia melihat nuklir sebagai teknologi penting yang harus dikuasai dan 
dikembangkan oleh Indonesia demi tujuan-tujuan damai. Maka, dalam politik nuklir internasional, Indonesia harus berdiri di atas prinsipnya sendiri.

Hal ini kemudian direalisasikan dengan membentuk lembaga khusus yang bergerak di bidang nuklir, sebagai pengawas sekaligus pengembang teknologi nuklir di Indonesia. Berdasarkan Keputusan Presiden RI No. 230 Tahun 1954 tanggal 23 November 1954, dibentuklah Panitia Penjelidikan Radioaktivitet dan Tenaga Atom (PPRTA). Syahdan, oleh karena lembaga ini memiliki keterbatasan, pemerintah menyusun PP No. 65 Tahun 1958 tentang pembentukan Dewan Tenaga Atom (DTA) dan Lembaga Tenaga Atom (LTA) pada 5 Desember 1958. Hal ini sekaligus mencabut Keputusan Presiden sebelumnya mengenai PPRTA. DTA bertugas memberikan nasihat politik kepada Dewan Mentei berkenaan perkembangan tenaga atom internasional serta membentuk dan mengatur LTA. Adapun LTA bertugas merencanakan dan membangun reaktor nuklir untuk tujuan perdamaian dengan mencari bantuan-bantuan dari luar negeri.

Dalam politik nuklir, Indonesia tidak hanya menerima bantuan dari AS, tetapi juga dari Uni Soviet. Bantuan dan kerjasama internasional dalam proyek nuklir di Indonesia adalah hal tak terelakkan mengingat proyek tersebut membutuhkan biaya yang tidak sedikit. Dalam kondisi sebagai negara berkembang inilah proyek-proyek nuklir di Indonesia mulai berkembang. Tak sedikit tenaga ahli nuklir Indonesia mendapat pelatihan dalam bidang keilmuan di AS, Uni Soviet, dan negara lainnya. Namun demikian, memasuki tahun 1960an, proyek nuklir di Indonesia tidak lagi sekadar pengembangan teknologi, tetapi telah bersifat politis.

\section{Dinamika Politik Luar Negeri Sukarno}

Sejak berdirinya negara Indonesia, Indonesia mengambil sikap bebas aktif sebagai garis politik luar negeri. Pemerintah Indonesia memadukan politik bebas aktif dengan politik bertetangga baik yang ditonjolkan dalam berhubungan dengan negara-negara tetangga, yang memiliki pandangan yang sama mengenai politik internasional menyangkut Perang Dingin. Sementara itu, di dalam negeri, keseimbangan politik dan ekonomi juga menjadi permasalahan tersendiri. Bahkan, pada periode 1950an, terjadi perubahan sistem pemerintahan, dari Demokrasi Parlementer menjadi Demokrasi Terpimpin. Demokrasi Parlementer dianggap kurang memberikan ruang kekuasaan bagi presiden, yang mana ditunjang oleh parlemen yang sangat lemah. Puncaknya, pada 5 Juli 1955 diumumkan Dekirt Presiden mengenai pembubaran Konstituante dan berlakunya kembali UUD 1945. Dekrit ini menandai berubahnya sistem pemerintahan parlementer menjadi presidensil.

Hal ini rupanya memengaruhi sikap pemerintah dalam politik luar negeri. Sejak era terpimpin, sikap politik luar negeri menjadi konfrontatif dan high profile. Kebijakan politik luar negeri Sukarno termaktub dalam Ketetapan 
MPRS No. I/MPRS 1960 sebagai Pedoman Pelaksanaan Manifesto Politik Republik Indonesia. Serta, keputusan DOA No. 2/KTPS//Sd/61 sebagai Garis-Garis Besar Politik Luar Negeri Republik Indonesia. Pada dasarnya, kebijakan politik luar negeri Indonesia arahan Sukarno tersebut memiliki tujuan menghapuskan imperialisme di seluruh dunia. Selain itu, pada masa ini, Sukarno menjalankan Politik Mercusuar dan Politik Konfrontasi. Politik Mercusuar bertujuan menjadikan Indonesia sebagai mercusuar bagi negaranegara dunia. Adapun Politik Konfrontasi merupakan sikap permusuhan antara dua negara akibat tidak terakomodirnya perbedaan kepentingan dari negara-negara yang bersangkutan, khususnya Malaysia kala itu.

Syahdan, Indonesia juga memutuskan untuk keluar dari PBB karena menurut Sukarno, badan internasional tersebut memihak kepentingan imperialisme. Sebagai konsekuensi yang terjadi, mau tak mau Indonesia semakin mendekat dengan Republik Rakyat Cina (RRC), yang bisa memberikan dukungan, khsusunya finansial. Hubungan diplomatik Indonesia dengan RRC telah terjalin sejak Mei 1953. Berkaitan dengan nuklir, RRC merupakan negara Asia pertama yang berhasil menciptakan sekaligus melakukan uji coba senjata nuklir. Pada 27 November 1964, Menteri Luar Negeri RRC, Chen Yi melakukan lawatan ke Jakarta. Dalam lawatan ini, ia menyampaikan akan memberikan bantuan kredit senilai 50 juta dolar untuk pembangunan perekonomian di Indonesia, khususnya untuk transfer pengetahuan di bidang teknologi. Bantuan ekonomi ini, memengaruhi politik nuklir Indonesia, karena selanjutnya pemerintah melakukan reorganisasi dan restrukturisasi atas LTA di Indonesia.

Pada 16 Oktober 1964, RRC berhasil melakukan uji coba bom atom. Hal ini semakin memikat Sukarno untuk bersepakat dengan pemerintah RRC dalam hal kerja sama politik luar negeri. Inilah yang kemudian membuat pemerintah melakukan reorganisasi terhadap Lembaga Tenaga Atom (LTA), dengan dilandasi pemikiran bahwa perlu adanya penggunaan dan pengembangan nuklir tenaga atom di segala bidang dan dalam segala bentuk - yang kemudian harus diawasi, diikuti, serta mendapat bimbingan dan sokongan dari pemerintah untuk kepentingan nasional dan pembangunan bangsa. Terhitung sejak Maret 1965, LTA berubah nama menjadi Badan Tenaga Atom Nasional (BATAN). BATAN diharapkan menjadi dasar-dasar program kerja untuk kepentingan nasional dengan dikeluarkannya UndangUndang No. 31 Tahun 1964 tentang Ketentuan-ketentuan Pokok Tenaga Atom.

Dalam epilog Bab kedua, disebutkan bahwa BATAN terbentuk dalam situasi politik yang mengalami perubahan dan penuh ketegangan. Reorganisasi LTA menjadi BATAN dapat dikatakan terpengaruh oleh situasi politik luar negeri yang terjadi. Dalam perubahan orientasi tersebut, terdapat gagasan Sukarno mengenai politik nuklir Indonesia dari yang awalnya menentang 
kepemilikan senjata nuklir menjadi berambisi untuk memiliki senjata nuklir sendiri.

\section{Politik Nuklir Sukarno di Mata Internasional}

Perkembangan teknologi nuklir di Rapublik Rakyat Cina (RRC) telah memengaruhi pandangan Sukarno terhadap arah perkembangan teknologi nuklir selanjutnya di Indonesia. Pada Kongres Muhammadiyah di Bandung, 24 Juli 1965, Sukarno menyampaikan pidato yang pada intinya dalam waktu dekat Indonesia akan memiliki senjata nuklir. Dalam pidatonya, Sukarno berusaha memacu kemandirian produksi dan ekonomi Indonesia, yang dikenal dengan istilah berdikari. Selain itu, Sukarno juga menyinggung tentang kemandirian Indonesia dalam memproduksi senjata. Pernyataan Sukarno tersebut menjadi indikasi terjadinya perubahan orientasi pengembangan nuklir di Indoensia, yang semula untuk maksud perdamaian (atoms for peace) menjadi kepentingan pertahanan militer. Sejak 1958, pengembangan teknologi nuklir yang diperjuangkan oleh Sukarno adalah untuk perdamaian. Namun, landasan perdamaian dan kemerdekaan yang bebas dari senjata nuklir tidak kunjung terealisasi. Baginya, imperialisme dan senjata nuklir adalah kombinasi dan musuh bersama yang harus dilawan oleh negara-negara yang cinta kedamaian. Maka dari itu, baginya, kepemilikan senjata nuklir adalah hal yang mutlak.

Subandrio selaku Menteri Luar Negeri kala itu beranggapan bahwa situasi dunia telah berkembang dan mengubah pandangan Indonesia dalam mengambil keputusan. Ini disampaikan pada 25 Agustus 1965. Sukarno juga mengumumkan bahwa Indonesia akan memiliki senjata nuklir berupa bom atom dalam waktu dekat. Hal ini mendapat dukungan dari masyarakat Indonesia kala itu. Kepemilikan senjata nuklir bagi Indonesia merupakan usaha untuk mennjaga Indonesia dari segala ancaman dan mempertahankan wilayah Indonesia dari neo-kolonialisme dan neo-imperialisme. Sukarno juga menekankan bahwa bangsa Indonesia harus kreatif dan mandiri. Kepemilikan senjata nuklir merupakan sebuah upaya politik berdikari yang diharapkan bisa bebas dari ancaman negara lain yang mengganggu jalannya revolusi. Sebulan pasca pidatonya di Konferensi Muhammadiyah di Bandung, Sukarno menyatakan bahwa pengembangan senjata nuklir di Indonesia senantiasa mengalami peningkatan yang baik.

Ketika berita tentang upaya Indonesia dalam membangun bom nuklir semakin senter pada tahun 1965, pemerintah Amerika Serikat (AS) beranggapan bahwa Indonesia tidak memiliki kapabilitas terkait hal itu. Menurut pihak AS, ada beberapa kemungkinan mengenai pernyataan Sukarno bahwa Indonesia akan memiliki senjata nuklir, yaitu: pernyataan tersebut hanya sebuah propaganda; pernyataan tersebut terkait kerjasama pemerintah Indonesia dengan RRC terkait uji coba bom atom RRC di perairan Idonesia; 
atau kredit uji coba bom atom tersebut akan diberikan kepada Sukarno dan Indonesia. Dari pernyataan tersebut menunjukkan bahwa AS memiliki sikap skeptis terhadap pengembangan teknologi nuklir di Indonesia. Berbagai bantuan teknis maupun finansial dalam bidang nuklir yang diberikan AS kepada Indonesia sebelumnya, membuat AS yakin bahwa Indonesia tidak mampu memgembangkan senjata nuklir.

Dalam kasus Indonesia pada 1965, salah satu determinan untuk memiliki senjata nuklir antara lain adalah pembangunan kepercayaan diri bangsa. Senjata nuklir yang dianggap oleh Sukarno sebagai alat pertahanan diri bangsa juga memiliki fungsi untuk memelihara perdamaian dunia. Pada sisi yang berlainan, keseimbangan kekuatan internasional kala itu memiliki dua pola, yaitu pola oposisi langsung dan pola kompetisi. Untuk kasus yang terjadi di Indoensia, terkait ambisi nuklir Sukarno pada tahun 1965, pola yang berlangsung adalah pola kompetisi, di mana tidak terjadi persaingan antara Amerika Serikat dengan RRC secara langsung. Namun, terjadi perebutan pengaruh dan bantuan kepada Indonesia.

Di media massa, para pejabat AS cenderung merespons klaim kepemilikan senjata nuklir Indonesia sebagai suatu hal yang mustahil. Pihak AS beranggapan bahwa kepemilikan senjata nuklir oleh blok komunis adalah sebuah ancaman teror bagi dunia. Meskipun AS dan sekutunya meragukan klaim Sukarno bahwa Indonesia akan membuat senjata nuklir dalam waktu dekat, hal yang sebenarnya mereka khawatirkan adalah kepentingan politik RRC untuk memakai wilayah perairan Indonesia bagi uji coba nuklir. Memasuki 1965, AS dan sekutunya sangat cemas atas kedekatan Indonesia dengan RRC dengan terwujudnya aliansi politik Poros Jakarta-Peking, yakni aliansi politik untuk menandingi kekuatan kapitalisme AS dan sebuah upaya untuk menciptakan masyarakat sosialis Indonesia. Sebelum Juli 1965, Amerika Serikat gencar melakukan intervensi di segala bidang untuk membendung segala gerakan progresif yang terafiliasi dengan komunisme di Asia Afrika. Tak menutup kemungkinan bahwa AS akan melakukan segala upaya untuk menghentikan upaya Indoensia memiliki dan menguji bom atom.

Ambisi Sukarno dalam mengembangkan senjata nuklir di Indonesia yang didasari atas semangat melawan neo-imperialis dan neo-kolonialis, hancur seketika pasca terjadinya G30S. Peristiwa ini mengakibatkan perubahan orientasi dalam berbagai bidang, termasuk di bidang teknologi nuklir. Sebelumnya, pada peringatan kemerdekaan 17 Agustus 1965, Sukarno mengumumkan aliansi politik poros Jakarta-Phnompenh-Hanoi-BeijingPyongyang yang bersifat anti imperialisme dan kapitalisme. Dalam pidatonya, Sukarno mengumumkan kebijakan militer antara lain mengenai rakyat yang akan dipersenjatai. Antara 16-18 September 1965, Sukarno memerintahkan Menteri Angkatan Udara, Omar Dhani untuk pergi ke RRC membicarakan tawaran RRC mengenai bantuan pemberian senjata-senjata ringan. Namun, 
nampaknya saat itu pemerintah RRC sudah melupakan rencana bantuan nuklir kepada Indonesia.

Bantuan-bantuan yang dijanjikan oleh RRC tidak pernah tiba di Indonesia. Bahkan, pasca peristiwa G30S, hubungan diplomatik antara RRC dengan Indonesia mulai merenggang, seiring dengan berkurangnya kekuasaan Sukarno. Dialog ekstensif antara keduanya yang dijadwalkan berlangsung 2 Oktober 1965 terkait bantuan pemerintah RRC nyatanya tidak pernah terjadi. Fadeli menuliskan bahwa meskipun kedua negara menjalin hubungan baik, namun rasanya tak mungkin bagi RRC membiarkan teknologi yang dimilikinya dialihkan begitu saja ke pihak lain. Tak hanya itu, stok materi fisik milik RRC sangat terbatas, sehingga tidak mungkin dibagikan kepada Indonesia.

Peristiwa September 1965 telah menandai perubahan politik Indonesia yang semakin bergeser ke arah kanan. Bahkan, terjadi dualisme kepemimpinan antara Presiden Sukarno dan Jenderal Suharto yang dianggap berhasil menumpas G30S. Sebagai pungkasan, pada 11 Maret 1966, kekuasaan Sukarno sebagai presiden resmi berakhir. Dalam pemerintahan Suharto yang anti komunis, hubungan diplomatik Indonesia dengan negara komunis resmi berakhir. Hubungan diplomatik dengan RRC dibekukan terhitung 30 Oktober 1967.

Hal ini menandai berakhirnya ambisi kepemilikan nuklir yang dicitakan Suakrno untuk menandingi negara-negara imperialis Barat, karena tak relevan dengan pemerintahan Suharto. Pada 19 Juni 1967, pemerintahan Suharto menandatangani perjanjian keamanan yang diselenggarakan IAEA. Persetujuan keamanan tersebut berkomitmen agar teknologi nuklir digunakan untuk maksud damai yang sedang berlangsung. Syahdan, upaya pengembangan teknologi nuklir di Indonesia diawasi secara ketat oleh IAEA. Orientasi politik pengembangan nuklir di bawah kepemimpinan Suharto berbeda sama sekali dengan yang pernah dicita-citakan Sukarno. Orientasi politik nuklir di bawah Suharto lebih menekankan pada pengembangan nuklir dengan maksud damai di bawah pengawasan ketat dunia internasional.

\section{Tinjauan Kritis}

Buku berjudul Nuklir Sukarno: Kajian Awal atas Politik Tenaga Atom Indonesia 1958-1967 sangat tepat dibaca oleh berbagai kalangan, tidak hanya bagi para sejarawan yang menggeluti kajian sains dan teknologi, tetapi juga bagi para ilmuwan atau insinyur sekalipun. Seperti yang dijelaskan Fadeli, penguasaan sejarah teknologi dan sains, terutama penemuan-penemuan terdahulu merupakan dasar ujian bagi kapasitas seorang penemu. Studi atas penemuanpenemuan terdahulu akan membuka peluang bagi seorang ilmuwan untuk menemukan penemuan baru. Dengan demikian, buku ini tepat dibaca oleh akademisi dari berbagai kalangan. 
Dalam buku ini, Fadeli mencoba menghadirkan wacana baru yang masih jarang dieksplorasi, yaitu hubungan antara politik dan teknologi pasca kemerdekaan. Seperti yang diketahui, narasi sejarah Indonesia pasca kemerdekaan didominasi oleh wacana politik, ekonomi, sosial, dan budaya. Buku yang berasal dari tugas akhir skripsi yang diterbitkan Marjin Kiri ini dilengkapi dengan dokumen arsip negara yang lengkap. Buku ini sangat komprehensif dan materi yang dihadirkan sangat mudah dipahami. Meskipun masih terdapat tanda tanya besar apakah secara riil teknologi nuklir di Indonesia di tahun 1965 sedang dikembangkan, tapi penulis dapat menjelaskan bagaimana proses berlangsungnya politik nuklir di bawah Sukarno secara detail. Mungkin tidak berlebihan jika menilai buku ini sangat kreatif dalam menghadirkan perspektif berbeda terkait terjadinya gejolak politik September 1965. 